\title{
Sanna Nyqvist
}

\section{Kirjallisuudentutkimuksen peruskysymysten äärellä Den litteraturvetenskapliga texten som genre -seminaari Helsingissä 3.12.2010}

Svenska litteratursällskapetin kirjallisuusjaoston järjestämä seminaari toi joulukuun alussa kuultavaksi vieraita naapurimaasta: pääpuhujia olivat tutkija Anders Johansson (Uumajan yliopisto), professori Anna Williams (Uppsalan yliopisto) ja dosentti Torbjörn Forslid (Malmön korkeakoulu). Lisäksi puheenvuoron käytti SLS:n kustannuspuolta edustava Pia Forssell. Seminaarin taustalla oli huoli kirjallisuudentutkimuksen tilasta ja asemasta ei vain yliopistoissa vaan myös laajemmalti. Millaisia tekstejä me tutkijat kirjoitamme ja mitä tehtäviä ne palvelevat? Miten ylittää juopa akateemisen työn käytäntöjen ja tutkimukselle asetettujen ideaalien välillä?

Esitelmissä ja niiden lomassa käydyssä vilkkaassa keskustelussa viitattiin useaan kertaan Hanne-Lore Anderssonin tutkimukseen Doxa \& debatt: litteraturvetenskap runt sekelskiftet 2000 (2008), jonka mukaan Ruotsissa kirjallisuudentutkimuksen aiheet ja muodot ovat muuttuneet hyvin vähän viimeisen viidenkymmenen vuoden aikana. Anderssonin tekemästä kyselytutkimuksesta paljastui lisäksi, että suurin osa kirjallisuudentutkijoista kokee itsensä ulkopuolisiksi omalla alallaan. Olisiko yksi syy se, että emme kirjoita sellaisia tutkimuksia, joita aidosti haluaisimme tehdä, seminaarissa kysyttiin.

Ongelmakohtina esille nousivat kovat julkaisupaineet, jotka pakottavat suoltamaan tekstejä sisällön kärsiessä sekä akateemisen kirjoittamisen konventiot, jotka tuottavat ennalta arvattavia tuloksia. Tässä mielessä tutkimussuunnitelmat ovat pahin tieteellisen tekstin lajityyppi: ne ovat massatehtailtuja, jäykästi muotoiltuja ja varman päälle kirjoitettuja tekstejä, joiden perusteella päätetään, millainen tutkimus saa rahoitusta.

Anders Johanssonin mukaan ruotsalaisissa yliopistoissa standardisoitu ajattelu on saanut vallan: enää ei uskalleta tai osata tarttua aidosti vaikeisiin, haastaviin aiheisiin ja etsiä niiden käsittelylle uusia muotoja. Tilannetta kuvaa Johanssonin oman oppilaitoksen laitoskokouksessa käyty keskustelu: siinä todettiin, ettei kriittisen ajattelun opettamista voi enää mainita oppiaineen yhtenä tavoitteena, koska se kuulostaa kovin negatiiviselta. Anekdootti paljastaa, miten jatkuvaa tuottamista painottava talouden diskurssi on ottanut ylivallan yliopistojen sisällä. Kyseenalaistamiselle ei jää sijaa.

Anna Williams puolestaan näki tieteellisen kirjoittamisen valmiiksi annetuissa muodoissa ongelman tutkijanidentiteetin kannalta. Jos omat aiheet ja tyyli vievät 
annettujen rajojen ylitse, joutuuko tutkija siirtymään yliopiston ulkopuolelle, kuten Olof Lagercrantz, Peter Englund ja Horace Engdahl ovat tehneet? Williams korosti oman tyylin löytämistä avaimena vieraantumisen ongelmaan. Kirjallisuuden oppiaineissa pitäisi kiinnittää enemmän huomiota tyylin ja muodon kysymyksiin ja ohjata opiskelijoita löytämään itselleen ominainen tapa kommunikoida.

Torbjörn Forslid lähti kartoittamaan kirjallisuudentutkimuksen tilaa sen menneisyyden kautta. Vuosina 1850-1960 kirjallisuudentutkimuksen keskiössä oli historia. Henrik Schückin kaltaiset tutkijat kirjoittivat kirjallisuushistoriaa laajasta kulttuurihistoriallisesta perspektiivistä. Toinen tärkeä lajityyppi oli elämäkerta, jota voi Forslidin mukaan pitää kirjallisuudentutkimuksen kehityksen ja merkityksen veturina. 1950luvulta lähtien historia- ja yksilökeskeisyys saivat väistyä lähiluvun tieltä, ja pari vuosikymmentä myöhemmin oppiaineen ammattimaistuminen johti teorian esiinmarssiin. Kehitys on samalla merkinnyt tutkimuksen potentiaalisen yleisön supistumista. Miten saisimme kirjallisuudentutkimuksen palautettua humanistisen tutkimuksen eturiviin ja lukijat kiinnostumaan teksteistämme?

Forslid etsi ratkaisua kolmelta taholta, jotka ovat kysymyksenasettelu, laajentaminen ja erikoistuminen. Kirjallisuudentutkimus on perinteisesti vaalinut kirjailijan asemaa, sillä elämäkerrallisen tutkimuksen ohella tekstilähtöinen tutkimus keskittyy usein tietyn kirjailijan tuotantoon. Sen sijaan voisimme lähestyä kirjallisuutta ilmiönä ongelmanlähtöisesti ja pyrkiä selkeisiin tuloksiin. Toiseksi meidän olisi jalkauduttava laajemmalle kentälle ja etsittävä uusia metodeja kirjallisuuden merkityksen ja muotojen tutkimukseen esimerkiksi kognitiotieteestä ja evoluutiotutkimuksesta. Kolmanneksi, koska yksi tutkija ei voi tehdä kaikkea, on erikoistuttava. Tämä tarkoittaa esimerkiksi tekstien räätälöintiä tietylle yleisölle.

Kustantajan näkökulmasta aihetta käsitellyt Pia Forssell korosti stilisoidun, huolellisen kielenkäytön merkitystä. Kirjallisuutta ei voi analysoida, jos ei itse hallitse kielen mahdollisuuksia, eikä kielellisesti onnahteleva teksti pysty houkuttelemaan lukijaa tai palvelemaan tiedonvälitystä. Vaatimus selkeästä, läpinäkyvästä kielestä kirvoitti yleisöstä kriittisiä kommentteja. Selkeyden vaatimuksen koettiin jättävän syrjään vaikeat kysymykset, joiden ilmaiseminen ei ole yksiselitteistä. Voiko hämäryydestä puhua selkeästi tuhoamatta sitä?

Esitelmissä ja keskustelussa tuli esille erilaisia käsityksiä kirjallisuudentutkijan tehtävästä. Onko kaikkein tärkeintä kysyminen vai vastaaminen? Adornoon ja Deleuzeen pohjaavan Johanssonin mukaan kirjallisuudentutkijan tehtävä on löytää kysymyksiä rikkomalla totutun rajoja. Forslid sen sijaan painotti aktiivisuutta vastausten etsimisessä ja oli valmis käyttämään olemassa olevia lajityyppejä erilaisten yleisöjen tavoittamiseen. Williamsin näkökulmasta olennaista on se, että tutkija tekee itsensä näköistä tutkimusta, koska se tuottaa aidoimmat ja relevanteimmat tulokset. 
Esitelmien perusteella Ruotsissa painitaan samojen ongelmien kanssa kuin Suomessa. Kaksi erottavaa tekijää kuitenkin nousi esiin. Anderssonin tutkimuksen kaltaista tieteensosiologista ja -filosofista otetta tarvittaisiin täälläkin herättämään keskustelua siitä, mitä teemme, miksi ja kenelle. Toiseksi ruotsin asema yleispohjoismaisesti ymmärrettynä kielenä näkyi siinä, että puheenvuoroissa ei juuri pohdittu vieraan kielen käytön asettamia haasteita. Johtuuko kirjallisuudentutkimuksen tekstien latteus siitä, että niitä yhä enemmän kirjoitetaan (ja luetaan) muulla kuin omalla äidinkielellä? Miten kielien välillä operoiminen vaikuttaa tutkijaidentiteettiin? Mitä muuta popularisointi voi olla kuin valtakielellä (englanniksi) julkaistun tutkimuksen osittaista kääntämistä tai referoimista omalla kielellä?

Den litteraturvetenskapliga texten som genre -seminaari onnistui pyrkimyksissään herättää keskustelua. Konsensukseen ei päästy, eikä siihen pyrittykään tärkeämpää tuntui olevan kirjallisuudentutkimuksellisen toiminnan tarkastelu monista lähtökohdista käsin. Seminaarista teki erityisen antoisan se, että esitelmien jälkeiseen keskusteluun oli kerrankin kunnolla aikaa ja että keskusteluun osallistui yleisön koko kirjo emeritaprofessorista perustutkinto-opiskelijoihin. Vaikka kyse on tutkimuksen tilasta ja haasteista, opiskelijoiden osallistuminen on eritoten tärkeää: hehän ovat tutkimuksen keskeistä kohderyhmää, alan tulevia asiantuntijoita ja popularisoijia, mille uralle sitten lähtevätkään. 